\title{
ANALYSIS OF THE ENVIRONMENTAL PROFILE OF STUDENTS FROM CATINGUEIRA, PARAÍBA, USING TWO ENVIRONMENTAL MEASURE SCALES
}

Laianne de Souza GUILHERME ${ }^{1}$

Pedro Silva dos SANTOS 2

Maria Raquel Bizerra de FREITAS ${ }^{3}$

Habyhabanne Maia de OLIVEIRA ${ }^{4}$

Edevaldo da SILVA $^{5}$

\author{
${ }^{1}$ Student of Biological Sciences, Universidade Federal de Campina Grande (UFCG), Paraíba, Brazil \\ (laiannesouza.2014@gmail.com) \\ ${ }^{2}$ Biologist, UFCG, Paraíba, Brazil. (pedrosantosjs88@gmail.com) \\ ${ }^{3}$ Student of Biological Sciences, UFCG, Paraíba, Brazil. (raquel-p-b@ hotmail.com) \\ ${ }^{4}$ Forest Engineer, UFCG, Paraíba, Brazil. (haby_habanne@hotmail.com) \\ ${ }^{5}$ Biologist, Doctor in Chemistry Professor of UFCG, Paraíba, Brazil. (edevaldos@yahoo.com.br). \\ *Corresponding Author.
}

Recebido em: 03/02/2016 - Aprovado em: 19/07/2016 - Disponibilizado em: 18/12/2016

\begin{abstract}
Environmental education enables the acquisition of knowledge that provides awareness of human beings for a better relationship with the environment. The ecological footprint is a sustainable tool that measures the disorder that man causes on the planet in relation to his lifestyles and consumption. The objective of this study was to analyze the socio-environmental profile of the students in Catingueira, Paraíba, using two scales of environmental measures: the ecological footprint and the scale of concern with the environmental consequences. The two measure scales (Ecological footprint $=25$ items and Environmental Concern = 12 items) were applied to 102 students. Students reached between 41 to 110 points for the ecological footprint, being ranked within a sustainable lifestyle. The scale of concern with the environmental consequences aims to classify individuals into three distinct concerns (egoistic, altruistic and biospheric) for their environmental concern. Students tended to have an egoistic concern, which is a concern with the environment around himself, being vehement actions in Environmental Education that provides students with thoughts and habits that consider the welfare and preservation of living beings.
\end{abstract}

Keywords: Environmental education. Ecological footprint. Sustainability.

\section{ANÁLISE DO PERFIL AMBIENTAL DE ALUNOS DE CATINGUEIRA, PARAÍBA, UTILIZANDO DUAS ESCALAS DE MEDIDAS AMBIENTAIS}

RESUMO: A Educação Ambiental possibilita a aquisição de conhecimento que proporciona a sensibilização do ser humano para melhor relação com o meio ambiente. A pegada ecológica é uma ferramenta sustentável que mede a perturbação que o homem causa no planeta em relação aos seus hábitos de vida e consumo. O objetivo deste trabalho foi analisar o perfil socioambiental dos alunos da escola do município de Catingueira, Paraíba, utilizando duas escalas de medidas ambientais: a pegada ecológica e a escala de preocupação com as consequências ambientais. As duas escalas de medidas (Pegada ecológica $=25$ itens e Preocupação ambiental $=12$ itens) foram aplicadas a 102 alunos. Os alunos atingiram entre 41 aos 110 pontos para a Pegada ecológica, obtendo uma classificação dentro de um estilo de vida sustentável. A escala de preocupação com as consequências ambientais objetiva classificar os indivíduos em três perfis distintos (egoísta, altruísta, biosférico) quanto à sua preocupação ambiental. Portanto os alunos tenderam a ter um comportamento egoísta, onde preocupa-se com o meio ambiente em torno de si, sendo veemente ações em Educação Ambiental que propicie aos alunos pensamentos e hábitos que consideram o bem-estar e preservação de todos os seres vivos.

Palavras-chave: Educação Ambiental. Pegada Ecológica. Sustentabilidade. 


\section{INTRODUCTION}

A few decades ago, the companies freely exploited natural resources without worrying about the damage it could cause to the environment (SOUSA, 2012), culminating in several environmental problems (LEÃO et al., 2013).

These problems are intensified by the lack of information, habits and more environmentally sustainable consciousness (JACOBI, 2003).

However, currently there has been a search for better understanding on how to minimize these environmental problems (CARVALHO, 2012), and in this context, it is vital to have a broader approach to environmental issues, with the integration of different areas of knowledge to promote changes in behavior and consumption habits of people (ANDRADE; QUARESMA, 2014).

Studies on the environment have gained prominence in the technical and scientific means of natural sciences because of its complexity and the need for more attention to environmental problems (OLIVEIRA et al., 2015).

In an attempt to diagnose or evaluate people with this problem, some measure scales were created, seeking to qualify the profile of the people regarding their consumption pattern and/or relationship with the environment and its resources.

Among these scales, the ecological footprint, first proposed in 1996 by Mathis
Wackernagel and William Rees, aims to analyze the impact of human being on the planet (ANTUN; BALDIN, 2013), evaluating the disruption that man causes on the planet and reporting the calculation of the area of productive land required to sustain the person's way of life (LAMIN-GUEDES, 2011).

Another scale used is the concern scale of the environmental consequences created by Schultz (2001). It seeks to measure how much people care about environmental problems, classifying them as egoistic, altruistic and biospheric.

Selfish people demonstrate environmental concerns for their own protection; people with altruistic profile is concerned with the harm that environmental damage can have on others; and the biospheric have a more holistic concern that involves himself, other people and the environment.

The objective of this research was to analyze the environmental profile of students from public schools in the municipality of Catingueira - PB, using the measurement scale of the ecological footprint and Schultz's.

\section{MATERIAL AND METHODS}

The survey was conducted from March to August 2015, with high school students from the school Inácio da Catingueira, in the municipality of Catingueira, Paraíba. 
The definition of the sample size $(\mathrm{n}=$ 102 students) was according to Rocha (1997), considering the total number of students enrolled in that high school and assuming a standard error of $10 \%$.

The environmental measures were applied: Sales' Ecological Footprint; Nunes (2009) and Schultz's environmental concern scale (2001).

The footprint scale consisted of 25 questions, each with four alternatives (A to D) of answer, with distinct scores $(\mathrm{A}=01, \mathrm{~B}=$ $03, \mathrm{C}=05 ; \mathrm{D}=07)$. The questions involved aspects related to housing (15 questions), transportation (5 questions) and food (5 questions) to assess the students' consumption pattern of natural resources. They answered it in about 30 minutes.

Schultz's (2001) environmental concern scale had 12 items, built on the model of Likert scale with seven levels of answers (level 1: no concern to level 7: complete concern). This scale aims to classify individuals into three distinct profiles (egoistic, altruistic, biospheric) as for their environmental concern. Each profile corresponds to a group of four items on the scale (Table 1).

Table 1 - Items adapted from Schultz's (2001) environmental concern scale, according to their classification (egoistic, altruistic and biospheric).

\begin{tabular}{llllll}
\hline & \multicolumn{1}{c}{ Egoistic } & & \multicolumn{1}{c}{ Altruistic } & Biospheric \\
\hline i1 & Me & i5 & People in my country & i9 & Plants \\
i2 & My health & i6 & All people & i10 & Marine life \\
i3 & My lifestyle & i7 & Children & i11 & Animals \\
i4 & My future & i8 & My brothers & i12 & Birds \\
\hline
\end{tabular}

Source: Authors.

The analysis of the Ecological Footprint data used descriptive statistics, with the quantification of the sum of individual points for each aspect analyzed (housing, transportation and food) and the total score, considering all the aspects together to verify the overall profile of students.

From the points obtained, students were classified as follows: 0-40 points, demonstrate overall concern for the environment; 41-110 points, is conscious about consumption habits; $110-150$, is a little conscious consumer; and 151 or more points, proved not to have any concern with the environment.

Schultz's scale was validated for its internal consistency by Cronbach's alpha test, applied to each group of items (egoistic, altruistic and biospheric). The answers to the seven levels of the scale were grouped into three for easier interpretation of results, considering: levels 1-3 (none to little concern); level 4 (indifferent); levels $5-7$ (reasonable to much concern).

To assess the possible significant differences in the levels of concern among the 
three profiles (egoistic, altruistic and biospheric), the Mann-Whitney test was used for statistical comparison, considering the probability level $\mathrm{p}<0.05$.

\section{RESULTS AND DISCUSSION}

\section{Ecological footprint and profile of students}

There were 102 students interviewed: $56.0 \%(\mathrm{n}=57)$ female and $44.0 \%(\mathrm{n}=45)$ male. In total, $86.0 \%(n=88)$ of them were between 14 and 17 years and only $14.0 \%(\mathrm{n}=$ 14) were aged between 18 and 21 years. The majority $(76.0 \%, \mathrm{n}=77)$ of them live with more than three people.

About half of the students $(50.0 \%, \mathrm{n}=$ 51) were concerned about the economy of water resources by turning off the shower while soaping $(57.0 \%, \mathrm{n}=58)$ and not leaving the tap open while brushing their teeth $(57.0 \%, \mathrm{n}=58)$. A similar percentage are for those who usually turn out the lights when leaving a room, $53.0 \%(\mathrm{n}=54)$, and $64.0 \%(\mathrm{n}$ $=65)$ just iron clothes once a week. However, about a third of the students $(37.0 \%, \mathrm{n}=38)$ wear clean clothes only once.

The habit of separating household waste is not yet part of everyday life for $82.0 \%$ of them $(n=84)$, and $67.0 \%(n=68)$ did not stop using plastic bags from the supermarket.

Almost all the students surveyed had the total score of the questionnaire in the range between 41 to 110 points (Figure 1), obtaining a classification of their ecological footprint within a sustainable lifestyle. Analyzing the individual scores by the aspects studied (housing, transportation and food), it was noted that the aspects related to housing and transportation were, respectively, the ones in which the students had the lowest scores, $48.4 \%(\mathrm{n}=49)$ and $91.0 \%(\mathrm{n}=93)$ of students scored below $50.0 \%$ (score of 53 and 18) of the total points.

Figure 1 - Total score of students to the questionnaire on ecological footprint with defined area (in blue) to the profile $100 \%$ of the students $(N=102)$.

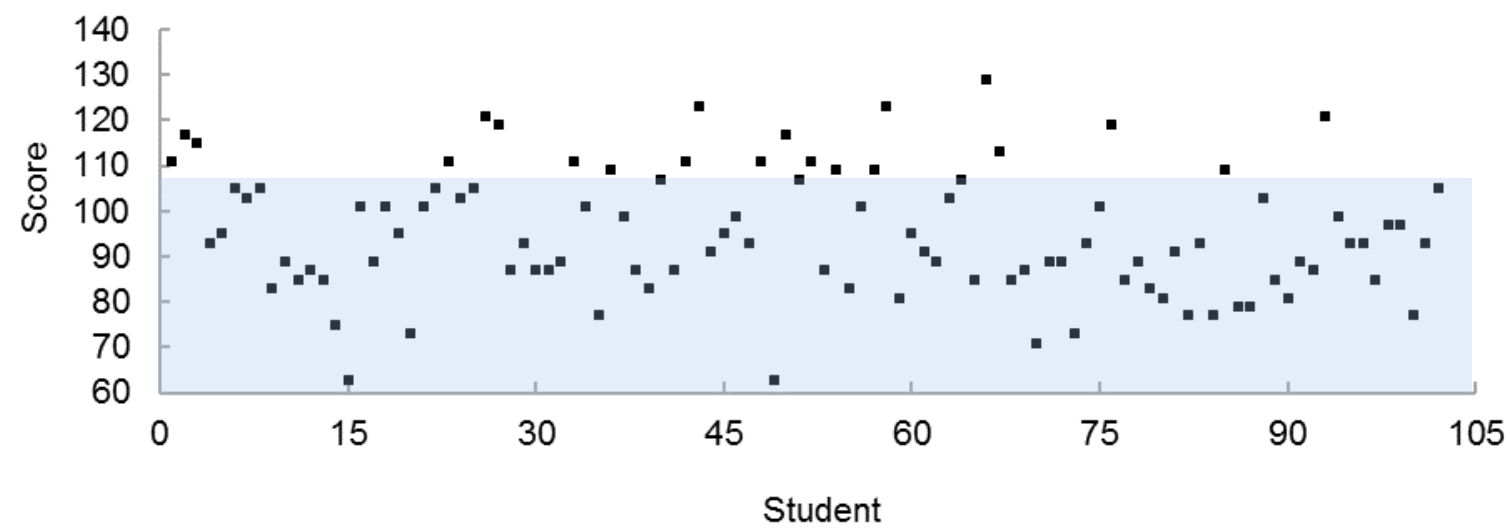

Source: Authors. 
According to the classification of the survey instrument, it demonstrates a sustainable way of life due to the fact that students possess more sustainable habits and behaviors regarding the use of natural resources.

For the aspect food, about $44.1 \%(\mathrm{n}=$ 45) of the students scored higher than $50.0 \%$ of the maximum possible, indicating that students' habits for this aspect were worse than those related to housing and transportation, probably due to eating habits that generate much environmental impact, such as daily meat consumption. (Figure 2).

Figure 2 - Frequency Histograms (\%) of overall score of students according to the aspects evaluated (Housing, Transportation and Food, $N=102$ )
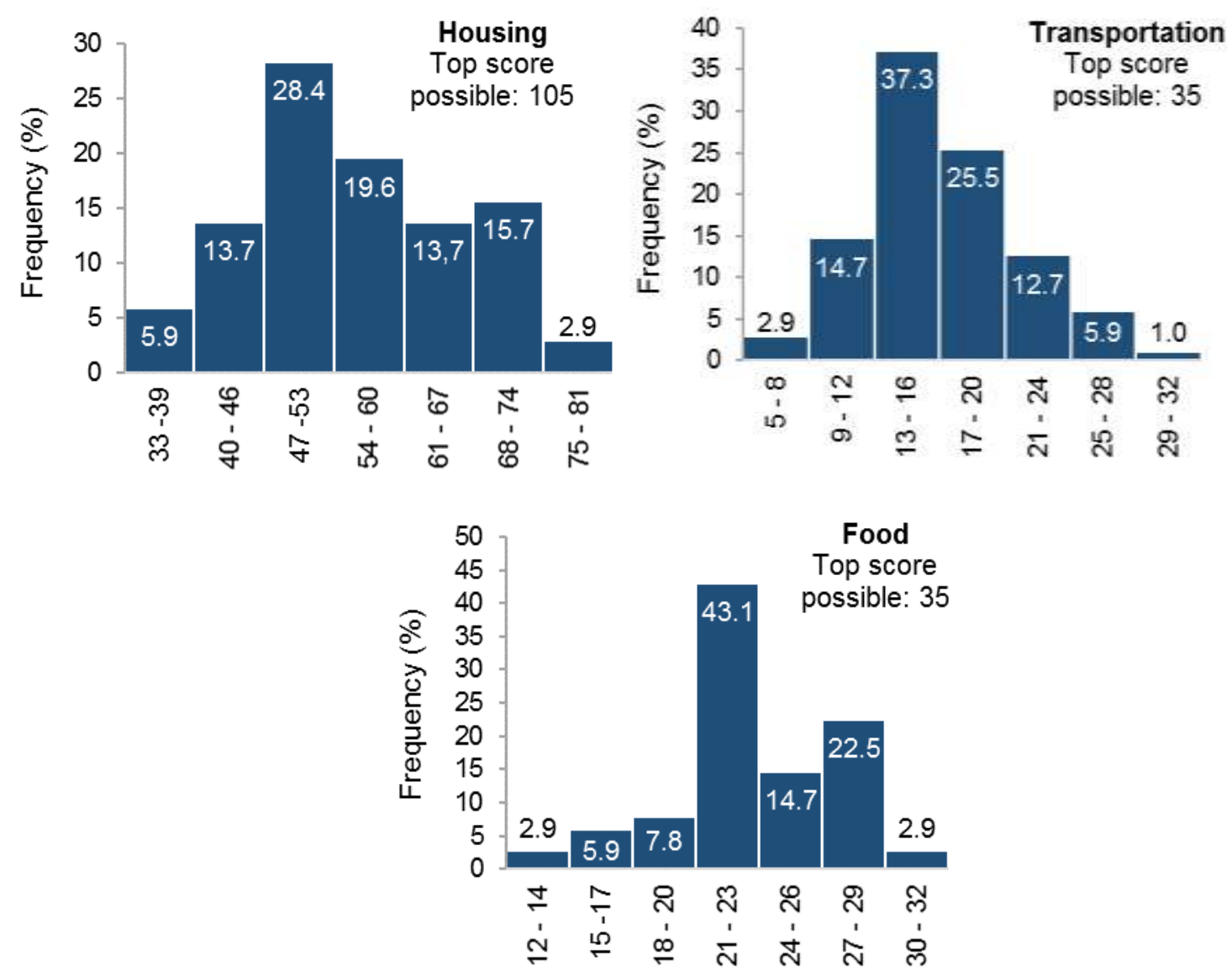

Source: Authors.

In general, the students had an Ecological Footprint within a sustainable standard of living and consumption, in which they thought about their spending habits in relation to natural resources. However, it is essential to raise their awareness to change a few habits that had been unsustainable, particularly on solid waste. 
They reported not having proper care about the destination and generation of solid waste, such as the habit of using plastic bags, which is quite disturbing. This probably occurs because of the lack of knowledge about environmental issues and the proper waste management.

To sensitize them, educational activities must become present in everyday life in the school field (FIDELIS, 2013), such as educational projects that focus on showing useful ways to use this waste rationally, preventing environmental damage caused by them (Souza et al., 2014).

In addition, succeeding in the educational process of efficient management in relation to the environment will occur when societies intensify their preservation methods, cultivating new values and principles for environmental management (SILVA; ALMEIDA, 2010).

Fachinni and Aguiar (2015) reported students' profile with less sustainable habits, compared to the students surveyed here, about the habits related to water and energy resources, where $97.1 \%$ of the students from São João da Boa Vista, São Paulo, left the tap running when brushing their teeth and $77.1 \%$ said they switched off appliances and lights when not using.

On the other hand, Fidelis (2013) reported that high school students of Maringa, Paraná, presented an ecological profile compatible with a sustainable standard of living and consumption. In addition, he found that the students were not too concerned about the environmental problems they are experiencing. Similar attitude was found in this survey for the habits related to solid waste.

Cajaíba and Silva (2014) also reported similar results regarding consumption habits, where $76.9 \%$ always turn off appliances and lights when not using, $80.8 \%$ open the tap only to wet the brush and to rinse mouth. However, the results of this survey were that $53.0 \%$ said they usually turn out the lights when they leave the rooms, and $57.0 \%$ of students do not leave the tap open to brush their teeth.

Each person's way of life is important to build a sustainable world. In a way, simple everyday actions can collectively cause serious damage to the environment. Thus, Environmental Education is highlighted as an important means to provide awareness about the preservation of nature (FIDELIS, 2013).

\section{Concern of students with environmental consequences: Schultz scale}

There were significant differences in the data reported between egoistic and altruistic concerns $(\mathrm{z}=9.27, \mathrm{p}<0.05)$ and between the egoistic and biospheric concerns $(\mathrm{z}=8.41, \mathrm{p}<0.05)$. However, there were no differences in the data of altruistic and biospheric concerns $(\mathrm{z}=0.00, \mathrm{p}<0.05)$. 
Therefore, the profile egoistic predominated in relation to the students' concerns about the environmental consequences, where $80.8 \%$ to $90.9 \%$ of them were concerned from reasonable to much with the environmental damage that could reach them (Table 2).

About a third of the students also had from an indifferent attitude to no concern for the environmental consequences that bring harm to plants $(35.3 \%, \mathrm{n}=36)$, birds $(34.4 \%$, $\mathrm{n}=35)$ and aquatic life $(41.4 \%, \mathrm{n}=42)$. In addition, between $45.5 \%(\mathrm{n}=46)$ and $53.6 \%$ $(n=55)$ of them said they have the same attitude (indifferent to no concern) in relation to environmental damage reaching others (neighbors, or everyone else, except their siblings).

Table 2 - Percentage frequency of students' responses to the concern scale with the environmental consequences of Schultz (2001).

\begin{tabular}{lccc}
\hline Item & None/Little & Indifferent & Reasonable/Much \\
\hline \multicolumn{4}{c}{ Egoistic concern $(N=99 ; \alpha$-Cronbach =0.781) } \\
\hline i1 Me & 7.1 & 7.1 & 85.9 \\
i2 My lifestyle & 10.1 & 9.1 & 80.8 \\
i3 My health & 6.1 & 3.0 & 90.9 \\
i4 My future & 4.0 & 5.1 & 90.9 \\
\hline \multicolumn{4}{c}{ Altruistic concern $(N=99 ; \alpha$-Cronbach $=0.714)$} \\
\hline i5 People in my country & 36.4 & 17.2 & 46.5 \\
i6 All people & 25.3 & 20.2 & 54.5 \\
i7 Children & 14.1 & 11.1 & 74.7 \\
i8 My brothers & 9.1 & 1.0 & 89.9 \\
\hline \multicolumn{5}{c}{ Biospheric concern $(N=99 ; \alpha$-Cronbach $=0.780)$} \\
\hline i9 Plants & 13.1 & 22.2 & 64.6 \\
i10 Marine life & 23.2 & 18.2 & 58.6 \\
i11 Birds & 15.2 & 19.2 & 65.7 \\
i12 Animals & 6.1 & 7.1 & 86.9 \\
\hline
\end{tabular}

Source: Authors.

These data report the need to insert aspects related to ethical human values in the school teaching, such as generosity, solidarity and respect for living things.

The low concern with nature can have negative consequences directly related to the misuse of natural resources (ALVES; ALVES, 2013).
Thus, much of the ecological instability is linked to inappropriate human habits generated from a consumerist lifestyle, caused by a capitalist society, which has consequences for the environment as the rampant use of natural resources (CUBA, 2010). 
People's concerns about nature is associated with the need to preserve their own survival and well-being, but enjoying the facilities that modernity provides (BECK; PEREIRA, 2012).

Environmental Education is a very important tool for the defense of nature, because it contributes to a rapprochement between man and the environment, and awakens in people the awareness for more respect towards nature, thereby providing a guaranteed future with better quality of life and well-being for societies (BELMIRO et al., 2013).

In this context, the involvement and the training of teachers for this environmental knowledge is fundamental (BIONDO et al., 2011; SILVA et al., 2015), wherewith they should provide students with a more critical environmental knowledge to be able to mediate this knowledge to better environmental habits.

Therefore, it is necessary for teachers to address the various issues and environmental problems in an inter- and transdisciplinary approach to Environmental Education so that students become social actors with biospheric environmental concerns.

The transversality grants the educator to perform better methods of interaction with the students, causing them to develop values, attitudes and concepts, which bring about better interaction between man and nature (SANTOS et al., 2010).

\section{CONCLUSIONS}

The ecological footprint scale reported that students generally have a profile with sustainable consumption habits. However, they do not report good habits related to solid waste they generate. According to data from Schultz scale, most students tended to have an egoistic concern for the environmental consequences.

The results reported by both measure scales were important tools to display and reiterate some weaknesses of students as for their practices and socio-environmental concerns, revealing the need to insert Environmental Education as a source of knowledge and awareness for a better relationship with the environment.

\section{REFERENCES}

ALVES, M. A.; ALVES, C. R. S. R. A temática ambiental no contexto escolar: Concepções de professores dos anos iniciais. Revista Educação Ambiental em Ação, n. 44, 2013.

ANTUN, A. E.; BALDIN, N. Pegada Ecológica: percepção de crianças em caminhadas na natureza. Revista Paranaense de Desenvolvimento-RPD, v. 34, n. 124, p. 245-265, 2013.

ANDRADE, C. D. M.; QUARESMA, A. G. Educação ambiental, desenvolvimento local e gestão social: Perspectivas para a escola. Revista Educação Ambiental em Ação, n. 50, 2014. 
BATISTA, R. O.; VALE, H. S. M.; PEREIRA, L. E. C.; COSTA, L. R. Desenvolvimento de sistema sustentável para captação de água pluvial em comunidades rurais do semiárido. Revista Educação Ambiental em Ação, n. 44, 2013. BECK, C. G.; PEREIRA, R. C. F. Preocupação ambiental e consumo consciente: os meus, os seus e os nossos interesses. Revista de Gestão Ambiental e Sustentabilidade- GeAS, v. 1, n. 2, p. 51-78, 2012.

BELMIRO, A.; CRISTINA, B.; FELISBERTO, C.; BATISTA, D.; ORLANDO, D. PEREIRA, R. Área verde benefício para a humanidade, saúde pública e qualidade de vida. Revista Educação Ambiental em Ação, n. 43, 2013.

BESERRA, E. P.; ALVES, M. D. S.; PINHEIRO, P. N. C.; VIEIRA, N. F. C. Educação ambiental e enfermagem: uma integração necessária. Revista Brasileira de Enfermagem-REBEn, v. 63, n. 5, p. 848-852, 2010.

BIONDO, E.; OLIVEIRA, E. C.; HARRES, J. B. S.; MARCHI, M. I. Dificuldades percebidas pelos professores da educação básica do Vale do Taquari/RS na aplicação de projetos de Educação Ambiental. Revista Educação Ambiental em Ação, n. 34, 2011.

CARVALHO, W. F. Educação ambiental como instrumento para preservação e proteção do meio ambiente: aspectos pedagógicos e jurídicos. Revista Visão Acadêmica, Universidade Estadual de Goiás, 2012.

CASALI, C. A.; SILVA, K. K. B.; BALEM, T. A. Percepção e educação ambiental de estudantes e professores das escolas de Julio de Castilhos, RS. Revista Educação Ambiental em Ação, n. 51, 2015.

COSTA, S. R.; SOUZA, P. A. R.; ZAMBRA, E. M.; ANDRADE, J. R. O Ensino
Educação Ambiental no Brasil: Discussões da última década. Revista Educação

Ambiental em Ação, n. 46, 2013.

CUBA, M. A. Educação Ambiental nas escolas. Revista de Educação, Cultura e Comunicação-ECCOM, v. 1, n. 2, p. 23-31, 2010.

FACCHINI, Y. M. G. A. AGUIAR, L. V. C. A pegada ecológica como instrumento de apoio para educação ambiental. Revista Brasileira de Iniciação Científica, v. 2, n. 2, 2015.

FIDELIS, G. A. Análise da pegada ecológica de alunos do Ensino Médio e perspectiva de desenvolvimento sustentável. Educação Ambiental em Ação, n. 43, 2013.

FONSECA, A. R.; ZUQUIM, F. A.; CORGOZINHO, B. M. S.; BRAGA, F. A.

Educação e pedagogia ambiental como conceito e proposta escolar. Revista Educação Ambiental em Ação, n. 41, 2012.

JACOBI, P. Educação ambiental, cidadania e sustentabilidade. Cadernos de pesquisa, v. 118, n. 3, p. 189-205, 2003.

LAMIM-GUEDES, V. Pegada ecológica: consumo de recursos naturais e meio ambiente. Educação Ambiental em ação, n. 38, 2011.

LEÃO, M. F.; OLIVEIRA, E. C.; DEL PINO, J. C. Educação ambiental: A busca por escolas sustentáveis e com vida. Destaques Acadêmicos, v. 5, n. 3, p. 153-162, 2013.

NUNES, T. C. O.; SANTOS, M. R. M. A educação ambiental na preservação dos corpos hídricos no Estado do Rio de Janeiro. Revista Educação Ambiental em Ação, n. 36, 2011.

OLIVEIRA, S. L.; BEZERRA, R. A.; RIBEIRO, R. L.; LACERDA, K. A. P. Análise de viabilidade econômica e ambiental de um sistema de captação de águas pluviais em residências. Revista Educação Ambiental em Ação, n. 51, 2015. 
SANTOS, J. SILVA, A. D. A. G.; SOUSA ALVES, S. G.; OLIVEIRA, R. G.; LUNA CAMBOIM, A. F. Concepção de educação ambiental e sua relação com a prática pedagógica de professores do ensino médio. Ciência \& Desenvolvimento-Revista Eletrônica da FAINOR, v. 8, n. 1, p. 229-249, 2015.

SANTOS, V. R.; SANTANA, A. R.; NAKAYAMA. L. Percepção Ambiental: Avaliação do perfil de cidadania ambiental dos estudantes dos cursos de licenciatura do Instituto Federal De Educação, Ciência E Tecnologia Do Pará (IFPA). Revista Educação Ambiental em Ação, n. 31, 2010.
SILVA, L. O.; ALMEIDA, E. A. Educar para gerir: Uma proposta baseada nos fundamentos da Educação e Gestão ambiental. Revista Educação Ambiental em Ação, n. 31, 2010.

SILVA, E.; SILVA, F. G.; SILVA, R. F. L.; SILVA, R. H.; OLIVEIRA, H. M. Avaliação do saber ambiental de professores do ensino público do município de São Bento, Paraíba. Scientia Plena, v. 11, n. 12, p. 1-11, 2015.

SOUSA, M. A. B. Análise de projetos de educação ambiental à luz das atividades da gestão do conhecimento. Revista Educação Ambiental em Ação, n. 41, 2012. 